\title{
Analysis of Factors Instigating Land Use Conflicts in Selected Forest Reserves of Ondo State, Nigeria
}

\author{
I. 0. Azeez ${ }^{1}$, 0. J. Aluko² \\ ${ }^{1}$ Department of Social and Environmental Forestry, University of Ibadan, Oyo State, Nigeria \\ ${ }^{2}$ Department of Agricultural Extension and Management, Federal College of Forestry, Forestry Research Institute of Nigeria, Nigeria \\ Email: azeezismail2000@yahoo.com, juliwal2002@yahoo.com
}

How to cite this paper: Azeez, I.O. and Aluko, O.J. (2019) Analysis of Factors Instigating Land Use Conflicts in Selected Forest Reserves of Ondo State, Nigeria. Journal of Environmental Protection, 10, 614-624.

https://doi.org/10.4236/jep.2019.105036

Received: April 8, 2019

Accepted: May 14, 2019

Published: May 17, 2019

Copyright () 2019 by author(s) and Scientific Research Publishing Inc. This work is licensed under the Creative Commons Attribution International License (CC BY 4.0).

http://creativecommons.org/licenses/by/4.0/

\begin{abstract}
Practice of agriculture and other none forestry uses in forest reserves often generates conflict owing to the former's incompatibility with the latter. The need to identify the factors that triggers this conflict is germane to sustainable forest resources management. Thus, this paper report findings on various factors instigating land use conflicts in the high forest zone of Ondo state, Nigeria. Idanre and Oluwa forest reserves in the state were purposively selected for the study. Household counting was carried out in order to obtain a population in each settlement using participatory rural appraisal (PRA) technique. Fifty percent sampling intensity of individuals in settlements within and around the sites was used to select a total of 302 respondents for the study. Primary data were collected using both interview schedule guide and focus group discussion. Means, frequency counts and percentages were employed for descriptive analysis while factor analysis was used to identify the various factors instigating land use conflicts. Majority of the respondents were male (80.8\%), married (86.1\%), Yorubas (69.9\%), farmers (69.6\%) with a mean age of $43 \pm 7.9$ years. Boundary dispute $(\bar{X}=2.60)$, Resource control conflict $(\bar{X}=2.31)$, Inheritance conflict $(\bar{X}=2.11)$ as well as conflict between human/cultural and natural use $(\bar{X}=1.66)$ were the major types of conflicts identified in the study area. Four major factors that amplified the causes of land use conflicts in the forest reserves were: Cultural (settling land dispute cultural values between different ethnic group and access to land ownership); Economic (desperate for short term monetary gain, unpaid rent to landlords and unauthorised sale of common or collectively owned land); Social factors (increase in number of people and several people claiming the same land), and Political factors (breach of contract with government and changes in government policies on the use of forest).
\end{abstract}




\section{Keywords}

Land Use, Land Use Conflict, Forest Reserve

\section{Introduction}

The importance of land-An environmental resource that includes all natural resources, cannot be overemphasized. This was reposed by [1] who submitted land as a finite resource, which provides a multitude of goods and ecosystem services that are fundamental to human well-being. Land is essential to many kinds of human practices as well as building of diverse human societies. Affirming this assertion [2], perceive land as an essential asset for economic, social and cultural activities.

In Nigeria, land is not only the primary means for seeking livelihood, also the main vehicle for investing and accumulating wealth as well as transferring wealth between generations [3]. This natural asset, which is vital for food, livelihood and environment security, is however under intense pressure especially the one under forest covers due to conflicts pertaining to land uses.

Land use conflicts had been observed by [4], to result in a variety of undesirable social, economic, environmental and cultural impacts ranging from minor to significant, short term to long term, and micro to macro in scale. These impacts have negative effects on individuals due to associated stress and anxiety, breakdown in communities, additional demands on government services, increased and costly demands on rural industries, degradation of the local environment, which can have flow-on effects for communities and businesses, and loss of culture and identity within communities. In situations where there is protracted land use conflict, access to land for production is reduced thereby leading to a shortage in production and availability of food.

Land use conflicts have direct and indirect implications on livelihoods of the people near the forest resources [5], was also of the same view that dwellers within and around forest areas often depend on forest resources for their sustenance. Previous studies have expounded the importance of forest resources [6] opined that forests generate a wealth of environmental services viz: Provision of habitats for biodiversity, guarding against water and wind erosion as well as desertification, aiding water infiltration into soils, and contributing to soil fertility. Similarly [7] noted that forest help to increase the resilience of landscapes and communities in the face of global change.

Ondo State is one of the most forested states in Nigeria, with about $16.4 \%$ of the total land area demarcated as forest reserves [8]. According to [9], agriculture (including fisheries and forestry) constitute the main occupation of the people of Ondo State, which provides income and employment opportunities for over seventy percent of the population. But like in most developing countries, this put intense pressure on forest and natural resources in the state. 
Land use transcends forestry and agricultural use boundary [10] submitted that the ways in which access to land is regulated, property rights are defined, and ownership conflicts are resolved has broad implications beyond the use of land. Thus, presence of agriculture and non-rural land use in one location can often generate conflict due to their potential incompatibility. In Ondo state forest reserves, rural dwellers face various land use conflicts and management problems, which [9] linked to overexploitation on forest resources and population pressure.

Existing literature on conflicts, particularly in forest reserves in Nigeria tends to be centered on land uses rather than matrices of problems ensuing from uses. The unfolding scenario in the Ondo state forest reserve is an example in this regard. The reserve has been a source of economic livelihood, sustaining people inhabiting within the reserves. However, in the last few decades, access to land has continued to diminish and this impact is being felt by dwellers that solely depend on the limited forest resources for their livelihood. It is, therefore, germane to properly determine the causal factors of these series of land use conflict so as to resolve the problems emanating from these phenomena.

\section{Objectives of the Study}

The objectives of the study are:

1) Describe the socio-economic characteristics of respondents in the study area;

2) Identify the land use activities in the study area;

3) Identify the types of land use conflicts in the study area;

4) Determine factors contributing to land use conflict in the study area.

\section{Methodology}

\subsection{Study Area}

The study was carried out in Ondo state Nigeria between the periods of February 2016-2017. The state has eighteen Local Government Areas (LGAs) viz: Akoko North-East, Akoko North-West, Akoko South-East, Akoko South-West, Akure North, Akure South, Ese-Odo, Idanre, Ifedore, Ilaje, Ile-Oluji-Okeigbo, Irele, Odigbo, Okitipupa, Ondo East, Ondo West, Ose and Owo Local Government Area. The state with a land mass of about $12,000 \mathrm{~km}^{2}$, has Akure as its administrative capital and lies between longitude $4^{\circ} 30^{\prime}$ and $6^{\circ} 0^{\prime}$ East of the Greenwich Meridian and Latitude $5^{\circ} 45^{\prime}$ and $8^{\circ} 15^{\prime}$ North of the equator. It enjoys two distinct seasons: The wet (between April and October) and the dry (from November to March) season [11]. The average annual temperature is $25.9^{\circ} \mathrm{C}$ while the average rainfall is 1546 in Ondo State, Nigeria [11].

Gazetted forest reserves in the state (Table 1), which lies mainly in high forest and savannah and mangrove ecological zones are in $3075 \mathrm{~km}^{2}$ of land area [11] Agriculture is a dominant economic activity and the main source of employment in the state providing employment and income for more than $75.0 \%$ cent of the population. Inhabitants are predominantly farmers, while women engage in food processing and trading in addition to farming [11]. 
Table 1. Agro-ecological zone.

\begin{tabular}{cc}
\hline Agro-ecological Zone (AZ) & Forest Reserves (FR) \\
\hline High Forest & Akure, Akure-Ofusu, Akure-OfusaExt, Ala, Idanre, \\
Savanna & Oluwa, Onisere, Otu, Irele \\
Mangrove/freshwater & Ipele-Idoani, Okelusi, Owo, Oyinmo, Ose, \\
\hline
\end{tabular}

\subsection{Sampling Procedure}

Four-stage sampling procedure was used for the study (Table 2). Purposive sampling technique was used to select High Forest agro-ecological zone based on past studies and reconnaissance survey on records of land use conflicts. Oluwa and Idanre forest reserves were purposively selected for the study from high forest agro-ecological zone on the same basis. Two settlements within and one around the selected forest reserves were then randomly selected to give a total of 6 settlements. The settlements were Makinde, Kangidi and Onipetesi in Oluwa and Omifunfun, Olowofeariwo and Jimbge in Idanre. Household counting was carried out in order to obtain a population in each settlement using participatory rural appraisal (PRA) technique. A 50\% sampling size based on the size of individual settlement was then used to select a total of 302 respondents for the study. Table 2 further reveals the sampling procedures employed for the study.

Using an interview schedule guide, primary data were collected on socio-economic characteristics of respondents, land use activities in the study area, types of land use conflicts in the study area and factors contributing to land use conflict in the study area. Identified land use conflict was operationalised on a 3 point scale of major, moderate and minor conflicts. The weighted mean for each item was obtained and used in the descriptive analysis while factor analysis was used to identify the factors that instigate land use conflict. The Kaiser Meyer Olkin (KMO) and Bartlett's test was used to examining the appropriateness of factor analysis [12]. The KMO value is used in comparing squares of simple correlation coefficient sum and the sum of squares of partial correlation coefficient, which explains the correlation among variables. $\mathrm{KMO}$ value is usually between 0 and 1 . The closer the value is to 1 , the higher the correlation among variables.

\section{Results and Discussion}

\subsection{Socio-Economic Characteristics of Respondents}

Data, as depicted in Table 3 revealed the majority (80.8\%) of the respondents, were male while $19.2 \%$ were females. This, however, does not imply that there are more male than female dwellers in the study area. It simply suggests that there are more male-headed households than those headed by the female. Age distribution (Table 3) revealed about $79.8 \%$ of the respondents as falling within the modal age bracket of 31 - 50 years. The mean age of the respondents was $43 \pm 7.9$. This indicated that respondents in the study area are in the active period of their life and are thus expected to partake in activities that will improve their livelihood [13] 
Table 2. An illustration of the sampling procedure and sample size.

\begin{tabular}{|c|c|c|c|c|c|c|c|c|}
\hline $\begin{array}{l}\text { Selected } \\
\text { Reserve }\end{array}$ & $\begin{array}{l}\text { Selected } \\
\text { settlement } \\
\text { Within }\end{array}$ & $\begin{array}{l}\text { Number of } \\
\text { Households }\end{array}$ & $\begin{array}{c}\text { Number of } \\
\text { Selected } \\
\text { Households } \\
(50 \% \text { S.P })\end{array}$ & $\begin{array}{c}\text { Retrieved } \\
\text { questionnaires } \\
\text { (within) }\end{array}$ & $\begin{array}{l}\text { Selected } \\
\text { Settlement } \\
\text { around }\end{array}$ & $\begin{array}{c}\text { Number of } \\
\text { Households } \\
\text { within }\end{array}$ & $\begin{array}{l}\text { Number of } \\
\text { Selected } \\
\text { Households } \\
(50 \% \text { S.P) }\end{array}$ & $\begin{array}{c}\text { Retrieved } \\
\text { questionnaires } \\
\text { (around) }\end{array}$ \\
\hline \multirow{2}{*}{ Oluwa } & Makinde & 114 & 57 & 53 & \multirow{2}{*}{ Onipetesi } & \multirow{2}{*}{122} & \multirow{2}{*}{61} & \multirow{2}{*}{56} \\
\hline & Kangidi & 52 & 26 & 24 & & & & \\
\hline \multirow{3}{*}{ Idanre } & Omifunfun & 141 & 71 & 70 & \multirow{3}{*}{ Jimgbe } & \multirow{3}{*}{114} & \multirow{3}{*}{57} & \multirow{3}{*}{53} \\
\hline & Olowo & 98 & 49 & 44 & & & & \\
\hline & Faerie & & & & & & & \\
\hline
\end{tabular}

Table 3. Distribution by socio-economic characteristics of respondents.

\begin{tabular}{|c|c|c|}
\hline Variable & Freq. & $\%$ \\
\hline \multicolumn{3}{|l|}{ Gender } \\
\hline Female & 58 & 19.2 \\
\hline Male & 244 & 80.8 \\
\hline \multicolumn{3}{|l|}{ Age } \\
\hline$\leq 30$ years & 7 & 2.3 \\
\hline $31-40$ years & 127 & 42.1 \\
\hline $41-50$ years & 114 & 37.7 \\
\hline $51-60$ years & 41 & 13.6 \\
\hline $61-70$ years & 13 & 4.3 \\
\hline \multicolumn{3}{|l|}{ Marital status } \\
\hline Single & 9 & 3.0 \\
\hline Married & 260 & 86.1 \\
\hline Divorced & 11 & 3.6 \\
\hline Widowed & 22 & 7.3 \\
\hline \multicolumn{3}{|c|}{ Educational background } \\
\hline No formal & 109 & 36.1 \\
\hline Primary & 66 & 21.9 \\
\hline Secondary & 106 & 35.1 \\
\hline Tertiary & 21 & 7.0 \\
\hline \multicolumn{3}{|l|}{ Ethnicity } \\
\hline Youruba & 211 & 69.9 \\
\hline Ibo & 19 & 6.3 \\
\hline Hausa & 19 & 6.3 \\
\hline Urobo & 21 & 7.0 \\
\hline Esan & 26 & 8.7 \\
\hline Ijaw & 4 & 1.3 \\
\hline Ijale & 2 & 0.7 \\
\hline
\end{tabular}

Source: Field survey, 2017. 
also reported a mean age of 43 years among forest reserve dwellers in South-West Nigeria, thus reposing this aspect of respondents' demographic index.

Based on the marital status of the respondents, it was observed that the majority (86.1\%) of the respondents were married. This has implication on population and the level of livelihood activities to sustain the population in the study area. This was agreed to by [14]. Also, population pressure is expected to increase demand for forest resources as well as competition on the limited resources in the forest reserve area. Analysis of data generated on respondents' educational status revealed that $36.1 \%$ of the respondents had non-formal education, $21.9 \%$ had primary education, and $35.1 \%$ had secondary education while $7.0 \%$ had tertiary education. Thus, some of the respondents had one form of formal education or the other [15] also had earlier reported a high level of post primary education among rural dwellers.

On ethnicity, the majority of the respondents were Yorubas (69.9\%) while the remaining $30.1 \%$ belong to various ethnic groups. It can be deduced from this finding that there is diversity in terms of ethnic background of dwellers in the forest reserves under study. Collaborating this finding [16] in an earlier study observed that Indigenes, as well as non-indigenes, are involved in the collection, processing and marketing of agricultural produce, thereby generating a regular source of income both for individuals and the settlements as a whole. This could, however, have negative effect on their coexistence considering the limited access to land (within their reach), which is the basis for agricultural productivity.

\subsection{Land Use Activities}

The distribution on land use activities as shown in Table 4 revealed that more than half (68.5\%) of the respondents were engaged in farming, $26.2 \%$ were involved in snail rearing and gathering, $22.2 \%$ were involved in gathering of Non Timber Forest Products. This implies that farming activity constitutes the major land use activity carried out by the dwellers in the forest reserve. This is in agreement with the finding of [13] in a similar study that farming is a predominant occupation and principal source of livelihood among forest reserve dwellers.

\subsection{Identified Land Use Conflicts}

Analysis of result in Table 5 revealed that boundary dispute $(\bar{X}=2.60)$ was the most prominent of identified land use conflicts in the study area. From the focus group discussions in the two forest reserves, it was discovered that farmers encroach into other farmers' land to expand individual production unit, which normally results in farm boundary dispute. Another form of boundary dispute identified through focus group discussions was the complexity of indigeneity. Here, the indigenes were of the view that the land belongs to their grandparents and as such, impose levies on non-indigenes and victimize those not complying with their terms. This contributed to conflict between indigenes and non-indigenes [17]. Also reported cases of conflict between inhabitants and 
Table 4. Frequency distribution of identified land use activities in the study area.

\begin{tabular}{cccc}
\hline Identified Land use activities & Freq. & $\%$ & Mode \\
\hline Crop farming & 207 & 68.5 & \\
Gathering of Non Timber Forest Products & 67 & 22.2 & \\
Lumbering activities & 24 & 7.9 & Crop Farming \\
Snail rearing and gathering & 79 & 26.2 & \\
Oil palm production & 16 & 5.3 & \\
\hline
\end{tabular}

Source: Field survey, 2017. ${ }^{\star}$ Multiple responses.

Table 5. Distribution by identified land use conflict.

\begin{tabular}{|c|c|c|c|c|c|c|c|}
\hline \multirow[b]{2}{*}{ Identified land use conflict } & \multicolumn{2}{|c|}{ Minor } & \multicolumn{2}{|c|}{ Moderate } & \multicolumn{2}{|c|}{ Major } & \multirow[b]{2}{*}{ Mean } \\
\hline & Freq. & $\%$ & Freq. & $\%$ & Freq. & $\%$ & \\
\hline Boundary conflicts & 29 & 9.6 & 100 & 33.1 & 173 & 57.3 & 2.60 \\
\hline Resource control conflicts & 28 & 9.3 & 149 & 49.3 & 125 & 41.4 & 2.31 \\
\hline Inheritance conflicts & 77 & 25.5 & 116 & 38.4 & 109 & 36.1 & 2.11 \\
\hline Land ownership conflicts due & 252 & 83.4 & 30 & 9.9 & 20 & 6.6 & 1.23 \\
\hline lack of land registration & 249 & 82.5 & 31 & 10.3 & 22 & 7.3 & 1.25 \\
\hline Multiple sales/allocation of land & 232 & 76.8 & 33 & 10.9 & 37 & 12.3 & 1.35 \\
\hline Limited access to land due & 240 & 79.5 & 27 & 8.9 & 35 & 11.6 & 1.32 \\
\hline Evictions by landlord & 230 & 76.2 & 21 & 7.0 & 51 & 16.9 & 1.41 \\
\hline Disputes over the value of land & 226 & 74.8 & 47 & 15.6 & 29 & 9.6 & 1.35 \\
\hline Forestry and agricultural land conflict & 206 & 68.2 & 41 & 13.6 & 55 & 18.2 & 1.48 \\
\hline Competing uses/right on state & 267 & 88.4 & 23 & 7.6 & 12 & 4.0 & 1.16 \\
\hline Illegal sales of state land & 286 & 94.7 & 13 & 4.3 & 3 & 1.0 & 1.05 \\
\hline Illegal lease of state land & 279 & 92.4 & 18 & 6.0 & 5 & 1.7 & 1.07 \\
\hline Improper land privatization & 282 & 93.4 & 16 & 5.3 & 4 & 1.3 & 1.06 \\
\hline Violent land acquisitions & 227 & 75.2 & 19 & 6.3 & 56 & 18.5 & 1.41 \\
\hline Illegal evictions by state officials & 218 & 72.2 & 39 & 12.9 & 45 & 14.9 & 1.40 \\
\hline Destruction of property & 173 & 57.3 & 55 & 18.2 & 74 & 24.5 & 1.64 \\
\hline Conflict between human/cultural/wildlife & 181 & 59.9 & 69 & 19.9 & 61 & 20.2 & 1.66 \\
\hline $\begin{array}{l}\text { Expropriation by the state without } \\
\text { compensation }\end{array}$ & 238 & 78.8 & 30 & 9.9 & 34 & 11.3 & 1.32 \\
\hline Sales of someone else's land & 254 & 84.1 & 26 & 8.5 & 22 & 7.3 & 1.23 \\
\hline Leasing/renting of someone land & 267 & 88.4 & 23 & 7.6 & 12 & 4.0 & 1.16 \\
\hline $\begin{array}{l}\text { Intra-family conflicts, especially in the } \\
\text { case of polygamy }\end{array}$ & 259 & 85.8 & 23 & 7.6 & 20 & 6.6 & 1.21 \\
\hline $\begin{array}{l}\text { Competing uses/right on common and } \\
\text { collective land }\end{array}$ & 278 & 92.1 & 16 & 5.3 & 8 & 2.6 & 1.11 \\
\hline
\end{tabular}

Source: Field survey, 2017. 
indigenes of a particular place in his work and also emphasised that issues of settlers and indigenes are one of the worst conflict experienced in Nigeria.

Resource control conflict ( $\bar{X}=2.31$ ) was the second potent conflict identified by the respondents' (Table 5) [18] also reported that "dispute may arise from conflicting interest over the ownership and use of resources between the stakeholders (farmers and farmers, herders and herders, herders and farmers). Resource use conflict was found to exist between timber contractors and farmers in the study area. This is corroborated by discussants during the focus group discussion in Idanre forest reserve with submission that:

The timber contractors are fond of destroying farm lands. In the processing of felling tree, farm lands are destroyed. This in turn leads to conflict between farmers and the timber contractor.

In a related development one of the stakeholders reported thus:

Conflicts normally exist between Indian hemp planters and farmers due to the illegal activities of these Indian hemp/weeds planters since it (Indian hemp) is toxic and as such affects soil fertility, which in the long run impedes farmers' activities.

This is why [19] submitted resource use conflicts as leading to overexploitation of the resources, since each resource user tends to guard their interests.

Furthermore, conflict associated with inheritance as a result of demise of the household head ( $\bar{X}=2.11$ ) was ranked third. Here, conflict erupts from non-satisfaction of inheritors with the size or location of land allotted to them. Attesting to this fact, one of the tenants in the reserve claimed that:

After the demise of the family head, there is usually much royalty demand on the land leased for farming by the new allottee. Apart from this, sharing formular of royalties may also result in conflict among family members.

Conflict between human/cultural and natural use $(\bar{X}=1.66)$ was ranked fourth. Wild animals such as buffalo and chimpanzee were reported through focus group discussion to attack dwellers on and off the farm, thus creating pandemonium and causing damages on cultivated lands. This would in variably have negative effect on rural people's livelihoods and lives. As earlier observed by [20] the continued reduction and fragmentation of natural habitat and feeding site of wildlife species through land use activities has led to the encroachment of wildlife into the farm lands in search for food, thereby leading to destruction of agroforestry trees, crops and dwellers. Other land use conflicts identified by the respondents include; expropriation by the state without compensation, illegal sales of state land, illegal eviction by state officials acting without mandate and dispute on the value of land, multiple sales/allocation of land.

\subsection{Factors Instigating Land Use Conflicts in Oluwa and Idanre Forest Reserves of Ondo States}

Kaiser-Meyer Olkinmeasure of sampling adequacy value of 0.731 was obtained and the Bartlett's test of sphericity was significant $\left(\chi^{2}(300)=3656.057, \mathrm{p}<0.05\right)$, indicating consistency with the recommended KMO cut off value of 0.60 as po- 
sited by [12]. Table 6 revealed that four major factors amplified the causes of land use conflict in Idanre and Oluwa forest reserve. These factors are: Cultural, Economic, Social and Political. Specifically, these are: Inadequate consultations in settling land dispute (0.564), Cultural values between different ethnic group (0.560), and Access to land ownership (0.554) under cultural factors. Under economic factors, the factors that loaded high were: Desperate for short term monetary gain (0.626), Unpaid rent to land lords (0.561), and Unauthorised sale of common or collectively owned land (0.623).

Regarding social factors, the variables that loaded high include: Increase in the number of people (0.721) and several people claiming the same land (0.567). The idea of increase in the number of people jostling for land could be attributed to rise in population coupled with limited resources, which consequently result in competition for available resources thus, culminating in land use conflict. This is evidenced in the Focus group discussion as reported by the discussants:

Considering the influx of people in recent times to the reserve, people tend to struggle for the available land in order to sustain their livelihood and as a result, individuals encroach into other people's farm lands which invariably lead to conflict.

This finding agrees with [21] submission that high population results in increased competition for land and decline in soil fertility.

Under political factor, two variables loaded high and that is breach of contract with government (0.673) and changes in government policies on the use of forest (0.644).

Table 6. Analysis of factors instigating land use conflict.

\begin{tabular}{|c|c|c|c|c|}
\hline \multirow{2}{*}{ Causes of land use conflict } & \multicolumn{4}{|c|}{ Component } \\
\hline & 1 & 2 & 3 & 4 \\
\hline inadequate consultations in settling land dispute & 0.564 & 0.162 & -0.116 & 0.284 \\
\hline unpaid rent to the landlords & 0.155 & 0.561 & 0.098 & 0.285 \\
\hline breach of contract with the government & -0.193 & -0.198 & 0.094 & 0.673 \\
\hline desperate for short-term monetary & 0.176 & 0.626 & 0.048 & 0.015 \\
\hline changes in government policies in the use of the forest & -0.241 & -0.138 & 0.091 & 0.644 \\
\hline access to ownership and land & 0.554 & 0.142 & 0.365 & 0.227 \\
\hline increasing in the number of people & 0.100 & -0.104 & 0.721 & -0.069 \\
\hline ignorance of the local community & 0.470 & 357 & -0.002 & 0.083 \\
\hline cultural values between different ethnic group & 0.560 & -0.206 & 0.017 & -0.004 \\
\hline eviction from the farmland & 0.208 & -0.303 & 0.190 & 0.503 \\
\hline concessionaire & 0.239 & 0.037 & 0.387 & 0.024 \\
\hline unauthorised sale of common or collectively owned land & 0.075 & 0.623 & 0.341 & 0.011 \\
\hline several people claiming the same land & 0.093 & 0.336 & 0.567 & 070 \\
\hline
\end{tabular}

Kaiser-Meyer-Olkin Measure of Sampling Adequacy 0.731. 


\section{Conclusion}

It is altruism that natural resources are imperative for life and growth. However growing demand for these resources has led to resource scarcity, unsustainable consumption and land use conflict, all of which was evident in the study area. Four major types of conflicts were identified in the study area viz: Boundary dispute, Resource control conflict, Inheritance conflict as well as Conflict between human/cultural and natural use. The study also articulated various dimensions to land use conflict ranging from cultural, economic, and social to political factors. Hence, understanding these dimensions of land use conflict in forest reserves, are more important in devising solutions. The study recommends the need to explore efforts that can reconcile the conflicts between livelihood gains and environmental costs in the forest area so as to ensure co-existence of inhabitants and sustained use of natural resources.

\section{Conflicts of Interest}

The authors declare no conflicts of interest regarding the publication of this paper.

\section{References}

[1] Smith, L., Case, J., Smith, H., Harwell, L. and Summers, K. (2013) Relating Ecosystem Services to Domains of Human Well-Being: Foundation for a U.S. Index. Ecological Indicators, 28, 79-90. https://doi.org/10.1016/j.ecolind.2012.02.032

[2] Franco J., Twomey, H., Ju, K., Vervest, P. and Kramer, T. (2015) The Meaning of Land in Myanmar. Transnational Institute, Myanmar, 1-39.

[3] Aluko, O.J., Abegunrin, O.O., Ajetomobi, O.O. and Osalusi, C.S. (2012) Impact of Displacement on Livelihood Activities of Dwellers in Omo Forest Reserves. Proceeding 6th Annual Conference on Research and Capacity Building for Agricultural Transformation, Federal University of Technology, Akure, 7-9 November 2012, 155-159.

[4] Leif, M. (2007) Land Tenure and Conflicts-Four Crucial Dimensions. Department of Social Anthropology, University of Bergen, Bergen, 2.

[5] Hagedorn, K. (2010) Forest Conflicts' Influence on Local People's Livelihoods: A Case of Conflicts between Timber Companies and Farmers in the Mankranso District of Ghana. 1-84.

[6] Aluko, O.J, Adejumo, A.A. and Samuel, O.F. (2015) Impact of Conflicts on Marketing of Selected Non Timber Forest Products around Omo Forest Reserve Ogun state Nigeria. XVI Forestry World Congress, Durban, South Africa, 7-11 September 2015, 1-8.

[7] Berrahmouni, N., Regato, P. and Parfondry, M. (2015) Global Guidelines for the Restoration of Degraded Forests and Landscapes in Drylands: Building Resilience and Benefiting Livelihoods. Forestry, Rome Paper, No. 175.

[8] Agbelusi, E.A. (1994) Wildlife Conservation in Ondo State. Nigerian Field, 59, 73-83.

[9] FORMECU (1998) Forest Resources Study Vol. II, Ondo and Ekiti State Forest Inventory, Management, Planning and Recommendations, FORMECU, Abuja, 55p.

[10] Deininger, K. and Binswanger, H. (1999) The Evolution of the World Bank's Land 
Policy: Principles, Experience, and Future Challenges. World Bank Research $O b$ server, 14, 247-276. https://doi.org/10.1093/wbro/14.2.247

[11] Facts and Figures of Ondo State (2007) Ministry of Finance and Planning, Department of Research and Planning. 2006 Edition, Akure, Ondo State, 24.

[12] Pallant, J. (2013) SPSS Survival Manual. A Step by Step Guide to Data Analysis Using IBM SPSS. 5th Edition, Allen and Unwin, Australia.

[13] Adekunle, V.A.J., Okunlola, J.O. and Oke, D.O. (2011) Management of Forest Ecosystem for Food Security and Rural Livelihood in South West Nigeria. Final Project Report for 2011 Start Grant for Global Change Research in Africa, 1-144.

[14] Ekong, E.E. (2003) Rural Sociology: An Introduction and Analysis of Rural Nigeria. 2nd Edition, Dore Educational, Uyo, Nigeria, 220-273.

[15] Oladeji, J.O. and Thomas, K.A. (2010) Effect of Conflict on Livelihood Activities of Rural Dwellers in Yewa Division Ogun State. The Nigerian Journal of Rural Sociology, 11, 62-70.

[16] Malleson, R. (1998) Community Management of Non-Wood Forest Resources: A Case Study from the Korup Forest, Cameroon. International Expert Meeting on Non-Wood Forest Products in Central Africa, Limbe Botanic Garden, Cameroon, 10-15 May 1998, 50-52.

[17] Sayne. A. (2012) Rethinking Nigeria's Indigene-Settler Conflicts. United State Institutes of Peace, Washington DC, 1-10.

[18] Hussein, K., Sumberg, J. and Seddon, D. (1999) Increasing Violent Conflict between Herders and Farmers in Africa: Claims and Evidence. Development Policy Review, 17, 397-418. https://doi.org/10.1111/1467-7679.00094

[19] Gombya-Ssembajjwe, W.S. (1996) Analysis of Institutional Incentives for Sustainable Management of Tropical Moist Forests: A Case Study of Mengo Forests. The University of Wales, Bangor, UK, 1-30.

[20] Olujobi, O.J., Sale, F.A. and Akande, O.M. (2013) Effect of Wildlife Species on the Activities of Agroforest Farmers in Ekiti State. Journal of Agriculture and Environmental Sciences, 1, 24-35.

[21] Agbeja, B.O. and Derkyi, M.A.A. (2011) Assessment of Conflicts between Forestry and Agricultural Land Uses in Nigeria and Ghana. Journal of Agricultural Science and Technology, 5, 462-471. 